\title{
Jason Allen-Paisant
}

\section{Body and Gesture in Derek Walcott's Theatre}

\begin{abstract}
Reflecting on Derek Walcott's early relationship with movement, dance and ritual, this article sheds light on the centrality of embodied memory in Walcott's work for the stage and reflects on the relationship between memory and materiality in his epistemology of performance. Walcott's ideas shaped his approach to dramaturgy in the late 1950s and position his work in relation to global debates around materialism (Brecht) and ritualism (Grotowski) in the theatre. A discussion of two plays, Dream on Monkey Mountain and Pantomime, examines the use of gestural language in specific performances of each. Such an approach demonstrates that the importance of embodied memory, as reflected in the staging of these plays, relates to certain Afro-Caribbean belief systems, which have exerted much influence on Walcott's work. The article also emphasizes how Walcott's theatre functions as a decolonial praxis that fosters the emergence of empowered subjectivities and Africanist modes of humanness that challenge the cultural order of colonialism. Jason Allen-Paisant is a lecturer in Caribbean Poetics and Decolonial Thought at the University of Leeds, and Director of the Institute for Colonial and Postcolonial Studies. He is currently at work on the monograph Staging Black Futures in the Twenty-First Century.
\end{abstract}

Key terms: embodiment, ritual, healing, Caribbean, African diaspora, dance, movement, memory, decolonization.

MOST CRITICISM of Derek Walcott's theatre has tended to deal with texts rather than performances. ${ }^{1}$ Relatively little attention, then, has been devoted to the way in which language is made to engage with the 'grammar and movement of the body' in Walcott's theatre, despite the importance of embodied memory in his staging practice. ${ }^{2}$ My concern in this article is the function of embodiment in Walcott's gestural and performative repertoire.

Significant for my discussion is the idea of the body as a site of gathering(s), a term that speaks about the body's power to bring together tangible and intangible worlds to sustain ancestral spirituality and celebrate the meaning of humanity in the face of extreme (neo)colonial violence and coercion. This idea of a 'meaning-making body' ${ }^{3}$ that stores and channels ancestral wisdom and spirituality as 'cultural capital in the context of extreme domination' is central in African/ diasporic performance and it serves here my reading of the body in Walcott's theatre. ${ }^{4}$ It resonates in the theories of Caribbean thinkers such as Sylvia Wynter and Rex Nettleford, which also enable a better understanding of embodiment in Walcott's work. In short, the emphasis here is the idea that the body gathers. Ancestral memories, 'forbidden but persistent gods', and cultural traumas from an unsettled past produce a representational excess, a bodily surplus, that transcends the capacity of verbal discourse on the stage. ${ }^{5}$ In the process, Walcott's theatre relies on the body as a site of circulation that enables the expression of 'nondominant memories excluded from the colonial archive'. 6

An analysis of performances of Dream on Monkey Mountain and Pantomime shows that the body is the primary stake within these productions. Such an analysis also shows the importance of Walcott's ideas that shaped the work of the Trinidad Theatre Workshop in the late 1950 os. 


\section{Embodied Memory and Ritual}

In the essay 'Meanings', Walcott reveals that a key result of the Rockefeller Foundation grant he received in 1957 for the study of theatre design in New York was an orientation towards what he calls a 'mimetic style' of acting.' This 'mimetic style' was also reinforced by his interest in Japanese film and Japanese and Chinese theatre, both of which he came to through his discovery of Brecht in 1958. Walcott was struck by the potential parallels between the preverbal expressiveness of Japanese films such as Ugetsu, Gate of Hell, and Rashomon and the 'mimetic Narrative power' of the AfroCaribbean gestural repertoire. ${ }^{8}$ What he felt was common to both was the ability of gesture to do 'the same thing as speech'. 9 Inspired by these parallels, he intended in Dream on Monkey Mountain to 'reduce the play almost to an inarticulateness of language'. ${ }^{10}$

Not only did Walcott discover Noh, Kabuki and Japanese cinema via Brecht, but he perceived resonances between Caribbean performance and the Oriental theatrical forms used by him, and sought to harness these homologies in his creation of a Caribbean theatre. ${ }^{11}$ Walcott saw in Brecht's de-emphasizing of the psychology of the individual character a means of foregrounding the theatre's ritual dimension, and this meant going beyond Marxist realism. Walcott's own tendency was to reduce psychological realism and intersubjective conflict in favour of the larger historical conflict between Afro-Caribbean cultural tradition and colonialism. This tendency is repeatedly manifested throughout his work, from the early allegorical play Ti-Jean and His Brothers to the later Pantomime. However, Walcott's 'epic' dramaturgy took on a different significance from Brecht's, even if Brecht inspired some of his ideas.

Brecht's motive for emphasizing the 'epic' in theatre was, of course, to historicize his performed material and to present it in its social and political context. Developing theatre as he did in the era of political decolonization in the Caribbean (the 1950s and 1960s), Walcott's concern was also with History. However, for him, placing dramatic action in historical context also meant foregrounding the theatre's identity and its role in preserving and maintaining Afro-Caribbean traditions within a hegemonic colonial order. His privileging of historical, 'epic' narrative rather than character psychology, and his utilization of allegory and symbol, was therefore linked to his foregrounding of ritual in the theatre. Walcott realized that ritual-making was a practice that was anticolonial, since it was based on ceremonies and spiritual practices that had been forbidden by colonial law. ${ }^{12}$ Colonial law had for centuries suppressed modes of subjectivity and human relations, which were antithetical to the forms required by capitalist production. In this sense, Walcott's approach to the political contrasted with Brecht's, since, in Walcott's worldview, ritual signified the preservation and affirmation of an anticolonial space through the theatre.

Linking ritual theatre practices (of increasing interest to Walcott in the late 1950s and early 1960s) with Brecht's dramaturgy based on Marxist materialist philosophy implied, then, a clash of worldviews. Brecht's aversion to celebratory or festive theatre is well known. For him, 'hypnotic music' appealed to unthinking emotion and favoured irrationalism, and as he saw it, the goal of 'epic theatre' was to appeal to reason. ${ }^{13}$ Ironically, however, it is the sense of rupture and alienation central to the Caribbean historical experience that has pushed notable Caribbean theatre-makers, including Aimé Césaire, Maryse Condé, and Rawle Gibbons, towards Brecht's concept of 'epic theatre' in the first place. Brecht's 'epic theatre', which he understands essentially as a challenge to the notion of historical inevitability, that is, the past as closed, archived, and irrecoverable, relies on a concept called Verfremdung, which refers to the critical gap created by the discrepancy between what is shown to the spectator and the sense of strangeness it provokes in them.

Verfremdung is the strangeness within the narrative that allows one to imagine this narrative differently. At its heart, therefore, is a drive to show the gaps within historical narrative that allow for the insertion of other perspectives, stories, and possibilities. Simply put, the act of 'making strange' (Verfremdung, in Brecht's terminology) is the process of 
allowing History to be viewed differently in a way that changes the relationship between the actor and their audience, but also the actor's relationship to themselves. We might call it 'renarrativization'. It is perhaps Benjamin who, echoing his own 'Theses on the Philosophy of History'," sums it up best: "It can happen this way, but it can happen quite a different way" - that is the fundamental attitude of one who writes for epic theatre. ${ }^{15}$ Accordingly, for Brecht, the idea of interruptions, and of History as an ever-present rather than closed arena - and the theatrical stage as a demonstration of this - is key.

What Walcott and other Caribbean theatremakers found in Brecht's theatre was the potential of challenging a linear forwardmoving conception of History with its ideas of progress and civilization; of shining light on the enduring consequences of imperial contact, which, to paraphrase Christina Sharpe, are afterlives that are not truly 'after' ${ }^{16}$ Brecht's epic theatre, with its focus on interruption, contradiction, non-linearity, and the rejection of tragic inevitability in the narrative of History, therefore seemed appropriate for staging the uneasiness of time in the Caribbean experience, where, because of the entanglement of the colonial past with the (post)colonial present and of the way this entanglement informs (both shaping and reflecting back) memory and life within an Afro-diasporic time continuum, History is experienced as a thing that persistently returns. Techniques of narrative distancing from the oral storytelling tradition and other illusion-breaking devices that Walcott uses in Ti-Jean and His Brothers facilitate this accentuation of the historical dynamics behind the fable itself. The influence of Brechtian technique, including montage, storytelling, choral work, and other interruptive techniques, is also perceptible in the text of his 1958 epic pageant Drums and Colours.

'Episodic' structure, cyclicity, interruptive devices, and chorality - features important to Brecht's 'epic theatre' - are also techniques central to Afro-Caribbean performance traditions. The ritual theatres of Vodou and Santería, for example, bring together 'music and poetry, dance and mime, acrobatics and trances, costume, make-up and masks, real "installations" combining man-made elements (paintings, sculptures, drawings) with natural ones (flowers, fruits, stones, etc.)' in an integrative experience. ${ }^{17}$ In these theatres, the categories of 'spectator' and 'actor' are not fixed ones and are antithetical to the separation of the audience from the spectacle. Walcott was able to establish a correspondence between these integrative Caribbean theatrical traditions and the illusion-breaking practices of Brecht's 'epic theatre'.

At the same time, however, the integrative character of Walcott's theatre produced unbridgeable contradictions with respect to Brecht's 'epic theatre'. For while Brecht aims for a kind of embodiment that emphasizes the individual as a product of his social and material environment, the individual's rational subjectivity is abstracted from the body, since body in Brecht's historical materialist imagination is not a part of mind as in the Caribbean imagination. In Brecht's portrayal of the individual, reason is understood as an autonomous faculty independent of the body and embodiment. His actor is conceived of as a living signifier who externalizes his or her emotions in an artificial manner that emphasizes their character's socio-political meaning. Such a conception of the actor's presence precludes the notion of collective memory and it retreats from the idea of spiritual connections between performer, audience, and the material world.

The contradiction, then, is that, while Brecht asserts the human as a product of its social environment, his practice is based on an abstraction of the body from that environment, insofar as dialectical materialism downplays the affective dynamics of the material world. To put it another way, Brecht's theatre was not a theatre of memory, and this is what Walcott pushes up against. With Walcott, the body is depicted both in its physical and nonphysical reality, even as the environment that shapes it is a material one whose imprint is felt in the realm of consciousness. The nonphysical, consciousness, and the spirit world all become extremely important.

Admittedly, this tension between ritual and materialist determinations is also present in post-war European theatre, coming to the fore particularly in the 1960s with 
practitioners such as Jerzy Grotowski and Peter Brook, and as the commitment to collective modes of work and communal lifestyles grew. While, on the other side of the Atlantic, companies such as the Living Theatre and Bread and Puppet saw ritual as a way of asserting and defining 'a radical group identity', this feeling became popular also in European theatre in the liberal climate of the 1960s. ${ }^{18}$ Given the rigidity of ideological polarities in the Cold War era, theatre-makers sought a new conception of radicalism that could redress the alienation produced by competitive individualism, on the one hand, and impotent Marxist intellectualism, on the other. ${ }^{19}$ The 1960s thus witnessed an increased interest in popular and sacred rituals that brought together the real and the virtual, and amplified the social power of magic and mysterious contagion among practitioners such as Jerzy Grotowski, Eugenio Barba, Carmelo Bene, and Jan Fabre, to name only a few.

In this conjuncture, a theatre of gestural and sensorial intensity, as realized by Grotowski and others of the 1960s, was presented as the sort that could most effectively achieve a direct, stark, and cruel representation of the social scourges that plagued the world. The idea was that, faced with the limitations of social realism, a theatre of tragic or cathartic ritual could be an aesthetic and ethical mode of placing the spectator face to face with the real image of the contemporary world. It is interesting that, although this tension would only come to occupy the forefront of EuroAmerican theatre criticism in the 1960s, Walcott, as a Caribbean man, was already grappling with it in the 1950 S Caribbean.

Walcott departed from Brecht in unambiguous ways, one of which was his affinity for a host of Afro-Caribbean spirit cosmologies, ontologies, and histories of sacred practices that were at his disposal. Various forms of Caribbean ritual performance - Vodou, Myal, Obeah, West Indian carnivals, among them had, for centuries, worked to neutralize power structures during colonialism. ${ }^{20}$ In a word, ritual theatrical forms, enlisting Afro-derived Caribbean ontologies, reflected the importance of the sacred in affecting the material conditions of existence in the colonized societies of the Caribbean. Common to all these practices was the importance of the 'language of the body', and the exponents of theatre in the Anglophone Caribbean in the 1950s and 1960s, including Walcott, sought to foreground the ways in which the body devised modes of survival, through performance mechanisms, in the context of slavery's confinements, a fact which entailed reflections on Caribbean cosmologies, myth, and ritual.

As such, Walcott felt that his players should build their own language by going deep into their organic, physical, and vocal impulses. His theatre was to be one which utilized all the physical powers of the actor, and which emerged from the depth of their being and their instinct, springing into a sort of translumination:

Every actor should make this journey [back from man to ape] to articulate his origins, but for these who have been called not men but mimics, the darkness must be total, and the cave should not contain a single man-made object. Its noises should be elemental, the roar of rain, ocean, wind, and fire. Their first sound should be like the last, the cry. The voice must grovel in search of itself, until gesture and sound fuse and the blaze of their flesh astonishes them. ... The actor must break up his body and feed it ruminatively as an ancestral storyteller fed twigs to the fire. . . Imitation was pure belief. We, the actors and poets, would strut like new Adams in a nakedness where sets, costumes, dimmers, all the 'dirty devices' of the theatre were unnecessary or inaccessible. Poverty seemed a gift to the imagination, necessity was truly a virtue, so we set our plays in the open, in natural, unphased light, and our subject was bare, unaccommodated man'. ${ }^{21}$

In describing his theatre as one that comes out of 'Poverty', Walcott displayed his awareness of the work of Grotowski, which, although in quite a different context, was based entirely on the corporeality of the actor, which was to be a 'total gift' in the performance space when the mask of the everyday had been stripped away. ${ }^{22}$ For Grotowski, the actor was a 'holy' person whose 'body must be freed from all resistance. The body must virtually cease to exist' so that they can reveal themselves as the new character. ${ }^{23}$ As a kind of 'high priest', they were the mediating pillar of a spiritual 
experience shared by performer and audience. This implied that the actor must play in a state of trance. For Grotowski, the actor's body and its spiritual capabilities were to be at the centre of the live experience of theatre. It constituted the theatre experience, dispensing with the modern mechanical accoutrements and technological prowess of Rich Theatre, and returning to the theatre's primitive roots.

Significantly, in the last twenty years of his career, Grotowski's research on Theatre of Sources involved the Afro-Caribbean ritual practices of Vodou, as documented by his former student James Slowiak. This research would on more than one occasion take him to Haiti, the first one from July 1979 to February 1980, when he studied Vodou practices with the Saint-Soleil community in the rural district of Kenskoff, near Port-au-Prince. ${ }^{24}$

Grotowski's work is referenced even more openly in the ensuing paragraph of Walcott's text, where, however, he uses it for a fierce critique of colonial power. For he saw the growing fascination for ritual theatre in Europe as an expression of remorse for acts of genocide and violence perpetrated by European civilization against the peoples it had colonized, and, belatedly, against its own self. Walcott therefore views with some irony the 'revivals of the primitive' within a civilization that, for centuries, had tried to erase it, while also actively attempting to wipe out 'primitive' traditions among the peoples it had colonized:

These self-soiling, penitential cults, the Theatre of the Absurd, the Theatre of Cruelty, the Poor Theatre, the Holy Theatre, the pseudo-barbarous revivals of primitive tragedy are not threats to civilization but acts of absolution, gropings for the outline of pure tragedy, rituals of washing in the first darkness. Their howls and flagellations are cries to that lost God which they have pronounced dead, for the God who is offered to slaves must be served dead, or He may change His chosen people. $^{25}$

In the final analysis, however, there can be no doubt that for Walcott, as for Grotowski, ritual, while immersing the spectator, also provokes recognition of something that lies beneath the surface of bodies and objects in the theatrical space. The idea was that the body, being the object of experience, could translate a sense of absent presence, tracing the outlines of memory in a context where so much had been done on an outer material level to erase the pre-colonial cultural memories of Africans and their descendants in the Caribbean. The body was therefore a 'field'. More than a corporeal mass containing a mind, it was a part of mind, bearing energies and memories - a portal of communication with the unconscious.

The body as living testimony was therefore indispensable in the language of performance, which Walcott sought to construct from 1957 onwards. His theatre invokes the capacity of the body to materialize the traumatic imprint of colonial violence in the performance space, reworking our understanding of colonial past and (post)colonial present in terms of accumulated presences. But by the same token, Walcott's theatre shows that the body as a living, breathing archive, fusing tangible and intangible memory, the world of the living with that of the ancestors, is able to invoke a different time-space to that of colonialism - a time-space of the sacred. It is therefore not at all surprising to observe in his work a tension between a traumatized body, on the one hand, and on the other, a body that itself provides an anchorage point for the self to transcend the terror of colonial oppression. This paradoxical fact evidences an African/diasporic sensitivity to rhythm and vibration as essential expression of the life force. The play Dream on Monkey Mountain offers a poignant illustration of this.

\section{The Gathering Body}

Dream on Monkey Mountain began to be written in 1958, when Walcott was in New York on a Rockefeller Foundation Fellowship for the study of scene design and directing. ${ }^{26}$ It was during this period that he sought to fuse 'the mimetic, the Narrative, and dance element' with 'the literary ... classical tradition', given his interest in both. ${ }^{27}$ If the so-called 'classical' influence was a colonial inheritance, the 'mimetic' dance element related to Afro-Caribbean 
traditions, which Walcott could not ignore, especially given the mandate of the St Lucia Arts Guild (Walcott's first company) and the Trinidad Theatre Company (his second) of producing a theatre that was truly Caribbean.

The play follows a surrealist dream structure in which the protagonist, Makak, is interrogated by Corporal Lestrade, a culturally alienated 'mulatto', and tries to tell his story to two of his fellow prisoners, Tigre and Souris. Makak has been arrested in a state of 'incomprehensible intoxication', we are told by Lestrade, as a result of a dream he claims to have experienced. The spectator relives Makak's dream in which the spectre of a woman appears to him. Makak describes the Apparition as a white goddess, though in Laveau's 1994 staging it was played by a Black actress dressed in a white gown and hat - a fact that complicates the portrayal of this figure as 'white' in an ethnic sense.

The Apparition announces to Makak that he is a descendant of African kings and that he should return to Africa. Emboldened and acting as a prophet, he heads to the village with his friend Moustique. When he cures a villager's fever in a highly ritualized healing scene, he convinces all the Black characters of the need to return to Africa. The rest of the play consists of a highly stylized 'journey back to Africa', which culminates in the ritualized apotheosis of Makak, his awakening from his dream, and his return to Monkey Mountain.

Walcott's overarching desire in this play, first staged in 1970, was for a theatre of ritual measures which would preserve an Africanist understanding of human subjectivity and of human relationship to Earth and its forces ('elemental' noises, 'the roar of rain, ocean, wind, and fire'). ${ }^{28}$ However, as he would be in Pantomime, Walcott is concerned with the psychic 'dissociation' that results from trauma. The play attempts to square these two concerns. The question was what impact could ritual performance have on the material conditions underpinning, and underpinned by, colonial violence.

The play foregrounds the idea of psychic 'dissociation' among Blacks who suffer from the myriad traumas bound up in race. The term 'dissociation' cannot be understood simply as a pathology in a Western sense. Western psychoanalysis is not always equipped to make sense of the kinds of 'splitting' of the psyche that result from racial trauma, since 'split subjectivity' is both an effect of racism and a resource in the face of colonial trauma. ${ }^{29}$ Walcott, who prefaces the published text of Dream on Monkey Mountain with an epigraph from Sartre's introduction to Fanon's The Wretched of the Earth, is aware of this. One manifestation of 'split subjectivity' in the play is the phenomenon of spirit possession. What is loosely called 'spirit possession', the welcoming of spirits and their embodiment in many indigenous and traditional societies, is often based on pre-colonial ontologies of selfhood that do not fit easily into Western epistemologies of thinking, acting, and being, and worse yet, into the norms that govern the extraction of resources and labour in the colonial economy.

In Haitian Vodou, for instance, the gods, who are necessarily personified and embodied, represent archetypes enshrined in ancestral narratives, phenomena that relate deeply to the Earth and the natural world. ${ }^{30}$ To be possessed or 'mounted' by the gods, or lwa, as they are called, is to manifest aspects of the life force and to express an intense connection to ancestral and non-human worlds. Spirit possession functions, then, as a refuge space for Afro-Caribbean communities in their struggle against colonial dehumanization. It reaffirms humanness through the foregrounding of an alternative, liberatory view of subjectivity and experience of the world. Spirit possession has been emphasized in various productions of Dream on Monkey Mountain, including Caroll Dawes's 1979 staging of the play in Jamaica, ${ }^{31}$ and Albert Laveau's 1994 Boston production at the Huntington Theatre (Figure 1 ).

Makak, the protagonist of the play, is a character who lives close to the Earth and with the spirit world in the deep forests of Monkey Mountain. These provide for him some form of escape from the commonplace dynamics of the colonial society. His is a different sense of the temporal, time not marked by humanity's interventions in the world, but by the wax and wane of the moon. On the one hand, he is 


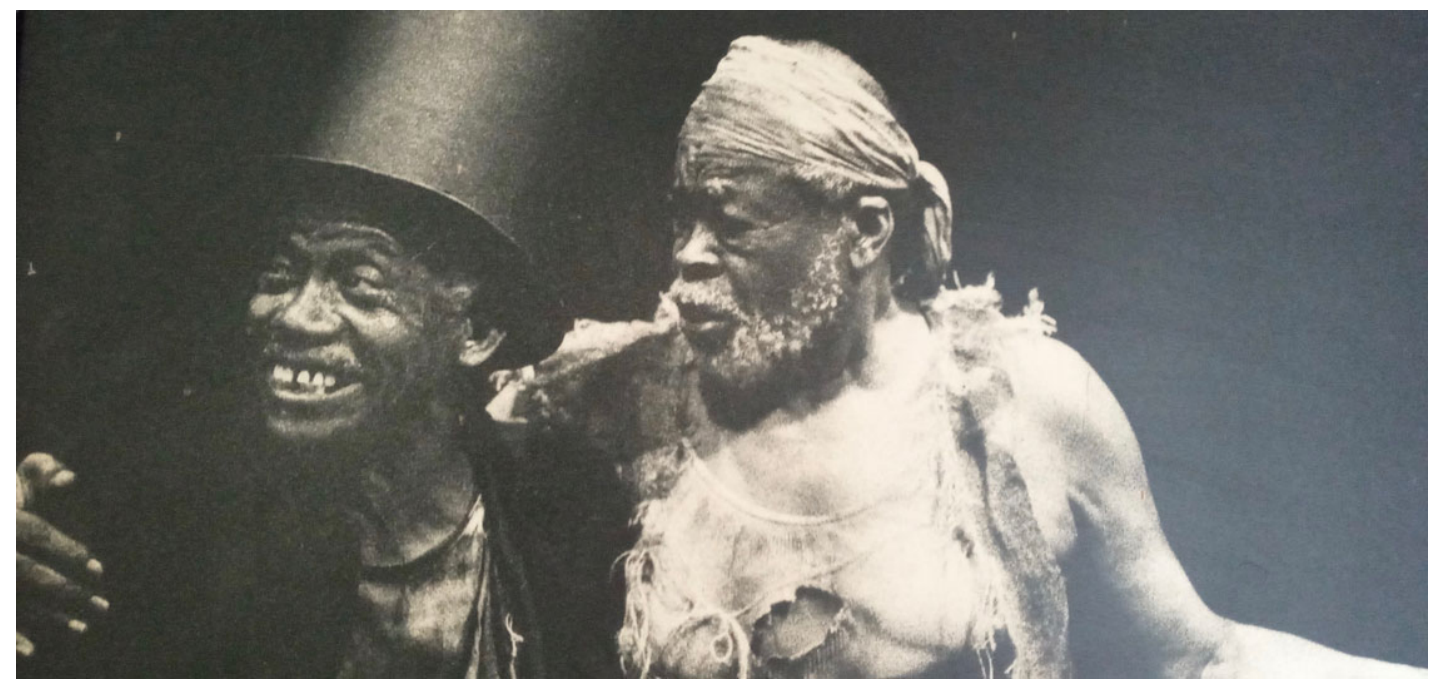

Figure 1. Stanley Marshall and Errol Jones as Moustique and Makak, in Dream on Monkey Mountain, directed by Albert Laveau, Boston, 1994. Photo: Abigail Hadeed.

afflicted by self-hatred because of his socioeconomic position within the colonial paradigm. His condition is associated with that of a slave, and, unsurprisingly, with that of a wild animal - makak is St Lucian Creole for 'monkey'. 'This is a being without a mind, a will, a name,' is how his accuser Lestrade describes him. ${ }^{32}$ On the other hand, Makak lives a kind of animist existence. He spends his days in the forest, walking and living among the trees. ${ }^{33}$ And his moments of spirit possession (what he refers to as 'fits') are moments of heightened wonder and attunement to the natural environment that surrounds him. Rather than physical oppression, these 'seizures' are moments of release for Makak, who surges away from the body, as it were, transcending, if only temporarily, the material conditions of the colonized life:

I fall in a frenzy every full-moon night. I does be possessed...

I feel my spine straighten,

My hand grow strong.

My blood was boiling.

Like a brown river in flood,

And in that frenzy,

I let out a cry,

I charged the spears about me,

Grasses and branches,
I began to dance,

With the splendour of a lion,

Faster and faster,

Faster and faster,

Then, my body sink,

My bones betray me

And I fall on the forest floor,

Dead, on sweating grass ${ }^{34}$

Makak is a primitive, but with him, primitiveness is a manifestation of a deep-rooted connection to Earth and the ancestral spirits, and takes on a mostly positive, if slightly ambivalent, value: he wants to go 'back home ... back to the beginnings, to the green beginnings of this world'. Makak thus embodies an attitude of being seized by the world, a sense of the immanence of human being-inthe-world, rather than human mastery, which is what the 'ordinary' people lack.

An exploration of spirit possession rites was inescapable for Walcott, who drew heavily on Afro-Caribbean ritual dances as part of a physically expressive, movementinspired theatre. After attending the dance summer school organized by Beryl McBurnie in 1957 at the University College of the West Indies, ${ }^{35}$ Walcott would later closely follow the activities of McBurnie's Little Carib Theatre in Trinidad as part of the development of his 
own practice. The programme for the Trinidad Theatre Workshop's 1968 tour of Trinidad and the Caribbean provides an indication of the continuing relationship of Walcott's theatre to McBurnie's practice-led research into West Indian folk dance, noting that 'scene III, the "healing scene", owes an obvious debt to Miss Beryl McBurnie's "Spirit"'. ${ }^{36}$ McBurnie introduced Vodou- and Shango-inspired choreographies, African survivals from Carriacou, as well as folk forms from Cuba, into her performance repertoire in the 1950s. ${ }^{37}$ Albert Laveau himself, who played in the Trinidad Theatre Workshop from the start, must have been marked by McBurnie's AfroCaribbean folk repertoire, which included spirit possession rites. This influence is apparent in Laveau's 1994 Boston production.

This production of Dream is a highly choreographed performance, with numerous danced sequences throughout. Music and dance support a kind of total theatre; they well up throughout the play as spontaneous, almost autonomous, elements of the performance, punctuating the dialogue. In Laveau's production, one notes the primacy of the drum, supported by other instruments, and song from an off-stage chorus hidden from view. The dancers appear, then disappear, only to return again and again, between and during the play's dream sequences. Soliloquies, including Makak's dream narrative of the Apparition, are often accompanied by music and dance.

The production opens with rhythmic drumming as the light rises to reveal dancers on a stage representing a clearing in a moonlit forest. They rotate their pelvises in a slow hipsaw movement, knees bent, arms pushing down and defining space between themselves and the rest of the body. The figure of Baron Samedi, Vodou lwa of the dead, appears and stands with legs astride among the dancers. As the drumbeat accelerates, the dancers' backs ripple. With slow rhythmic contraction and release of the backs, gradual extension of the forearms, the dancers deliberately command the space, demarcating a site of ceremony, as we hear the multiple rhythms of the drums. There are whirls and codified gestures of spirit possession as the dancers tie whitefringed skirts to their hips. The dancers appear, not as individualized characters in a tableau, but as a moving mass of bodies. The dance uses all these resources to achieve a constant return to an ancestral world. Observing the performance, one might feel like a participant in, as well as a spectator of, a ritual gathering. There is a sense of dance as an act of celebration and affirmation of life. However, at the same time, it is a material embodiment of an underlying disturbance or interruption, the 'interruption' constituted by slavery and colonialism in the collective narrative.

Dance constitutes an aesthetic of interruption, embodying a fundamental rhythm, a kind of 'return beat'. Sound and movement emphasize the idea of an embodied place for the ancestor, enabled through a collective corporeal beat, waging war against the everyday logic of containment. In Laveau's production, somatic convulsions bursting the seams of articulated language, through chorus, drumming and dancing - like the expression of a second, hidden language welling up behind words - sometimes approach actual ceremony. The play's 'healing scene', the point in the 'dream' at which Makak (played by Errol Jones) cures a dying villager of his fever, is one such example. The leg of the young man stiffens, his staccato movements indicating that he has been 'mounted' or possessed by a spirit. The dancers erupt into festive, heraldic dancing. As the chorus chants in Haitian Creole, the drums beat to a crescendo as the spirits re-open the flow of life. Dance is the embodied manifestation of a dynamic, fluid universe, of an ancestral connection, of the porosity between seen and unseen worlds. One of its main functions is, as Sylvia Wynter puts it, 'the strengthening of the forces of the Earth ... [and] the reaffirming of the ties with the ancestral spirits and the community, and the Earth, through possession' ${ }^{38}$

\section{Reparative Ritual}

Walcott was at times conflicted about the role of ritual in anticolonial resistance. The Fanonian paratext that he uses in the published text 
seems to question the power of cathartic ritual and its effectiveness as a decolonial praxis:

Thus in certain psychoses the hallucinated person, tired of always being insulted by his demon, one fine day starts hearing the voice of an angel who pays him compliments; but the jeers don't stop for all that; only from then on, they alternate with congratulations. This is a defence, but it is also the end of the story. The self is dissociated, and the patient heads for madness. ${ }^{39}$

Various soliloquies convey the idea that rites of healing and rituals to 'repair' an aberrant social order have had little impact on the large-scale organization of power and on material conditions over the centuries. This aspect of the play conveys a deep-seated Fanonian scepticism concerning the liberating power of ancestral spiritual practices. ${ }^{40}$ Some of Walcott's writings from the time show a playwright and company director heavily preoccupied with these conflicts:

Our dances of celebration are performances without a votive character. They are athletic challenges whose motivation is faded, whether they are meant to dramatize blood offerings or to perpetuate forgotten gods. They have found their sacred ground, in nightclubs and tourist hotels, and the more they are performed the more they avoid offence and elation ... The sacred ground is open to visitors who want to catch the spirit or photograph possession. ${ }^{41}$

Given the above remarks, what does his repeated use of ritual frameworks in plays such as Drums and Colours, Dream on Monkey Mountain, Ti-Jean and His Brothers, and Malcochon represent? It is clear that the idea that ritual does things is central to Walcott's work. Foregrounding the relationship between the world of the living and of the ancestors is not just a creative act, but also a counterimagination to a system of racist alienation. As a Caribbean cultural critic and theatremaker, he was aware of the importance that many Afro-Caribbean communities, including Haiti, ascribed to ancestral ritual practices a means of resisting coercion. If he consciously invested these in his theatre, it was not merely in a gesture of romanticization of the precolonial past, or even of destabilizing
Eurocentrism on the theatre stage, although that too was important; it was also a gesture that spoke to the 'truth' inherent in these practices.

'The dancer, for instance,' Walcott remarks, 'finds himself shedding artifice the nearer he gets to belief, but he must withhold surrender' in the interest of formal concerns, that is, if theatre is not to be pure ritual. ${ }^{42}$ Ritual therefore had a significance that Walcott could not get around. If he struggled to define what that significance was, a work such as Dream on Monkey Mountain foregrounds ritual as a corrective, reparative measure in which another temporality comes into play. Whatever the measure of 'effectiveness' that one uses to assess the impact of ritual in Caribbean society, one must agree that ritual seeks to repair the separation of essence from self and thus functions as an insurgent form of living and knowledge practice, waging war against alienation. Christopher Balme's invocation of a series of Walcott's statements from the essay 'What the Twilight Says' in support of his conclusion that, in infusing Africanist rituals into its work, Walcott's Trinidad Theatre Workshop was 'ultimately dealing with an alien mythology", 43 does not extend very much into an interpretation of the deeper meanings of ritual in Walcott's theatre.

In Dream, it is obvious that ritual's purpose goes beyond the mere rehearsing of traumatic memory, and that a ceremony that remembers the dead is something that galvanizes a response: a futures orientation that opposes the death-generating system of capitalism through its re-spiritualization of existence. In other words, ritual represents an articulation of existence from the very foundation of one's being. Ritual's power is in the idea of gathering. This impulse comes from the awareness of the body as a site of habitation.

Faced with the 'paralyzing' system of colonial law and its societal construct (embodied in Corporal Lestrade), Makak symbolizes the dream of the neutralization of colonial power through the spirit world, a dream which has been central to different Caribbean anticolonial movements, from Revivalism to 
Rastafari. This dream is that, through ritual power, one can achieve a kind of repossession of self, even if the material conditions of freedom remain unrealized. In the space of ritual, as Makak's new-found 'power' suggests, the human made abject through colonial alienation can reconnect with life. Despite the conditions that inscribe him in 'the status of living dead', the body can live again through the resources of the spirit world. Makak's newly acquired power to heal is a poetic metaphor for the individual's ability to 'become another' through their profound identification with the forces of the natural world. The body is central to this idea of becoming-other, since it constitutes a threshold between the world of the living and the spiritual world. It is the gateway through which the gods and ancestors enter the world of the living.

This emphasis on the necessary connection between memory and materiality urges us to view them in the light of each other. If, from the first, Walcott plays on the tension between ritualism and materialism (which, as outlined above, reflects his engagement with Brecht and with post-war theatre more broadly), any dualism between embodied memory and materiality is effectively erased in plays he creates from 1959 onwards. The organic relationship between memory and materiality was already heightened by virtue of the embodied dimension of both colonial violence and the performance dynamics that emerge in response to it. A work like Dream on Monkey Mountain shows that he was already deeply aware of this. This dynamic is also vividly depicted in Walcott's later play Pantomime.

\section{The Body as Living Testimony}

Pantomime's outwardly naturalistic framework is undercut by a highly gestural dramaturgy in which much of the meaning is communicated through rhythm, movement, and stylization. Rather than foregrounding psychological realism and individualism, the staging relies on the body as a retrieval vehicle for memory. Gesture and movement create their own territory of reality.
In the play, Harry Trewe, a white hotel proprietor, decides to act out Daniel Defoe's famous novel Robinson Crusoe, and decides to cast Jackson, his Black Tobagonian employee, in the role of Man Friday. After a lengthy dispute over the roles, during which Harry initially pretends to be unaware of the problematic nature of the narrative, Harry finally relents and agrees that Jackson, the Tobagonian native, is to play the sailor, who, in a radical reversal of Defoe's text, will be called Friday. Consequently, Harry Trewe, the English hotel proprietor, is to play the native, who is now known as Crusoe. However, Jackson will not be content with simply being an actor playing a fictional role. His intent is to humiliate Trewe, the actor who plays 'native Crusoe', and to make clear the power that he now holds.

Unable to endure this humiliation, Harry Trewe is forced to unmask his faux naïveté and to put an end to the sketch, the 'rehearsal' for an 'evening entertainment' programme that Trewe had planned for the guests at his hotel. His hypocrisy having been called out, Trewe is made angry by his failure and, refusing to continue the 'play', he orders Jackson back to work on the hotel's sun deck. Jackson, a mere factotum, but a highly intelligent one, is forced to comply because of the power relations. However, at this point, the audience witnesses the physical expression of Jackson's anger that arises from his accumulated frustration: at Harry's decision to re-enact the Robinson Crusoe story, at his feigned unawareness of the ordinary violence that such a re-enactment represents, at his hypocrisy in calling off the performance when the roles do not suit him, and at his refusal to acknowledge the historical trauma that this has reactivated in his Black employee. Ultimately, Jackson is placed in a situation where he is forced to relive the pain of colonial objectification at the hand of his self-absorbed white boss (Figure 2).

The play's conflict is very much an ideological one. While ideology is typically associated with discourse, its often obscured aspect is its embodiment. Jackson is aware that ideology implies the power of the organization of 


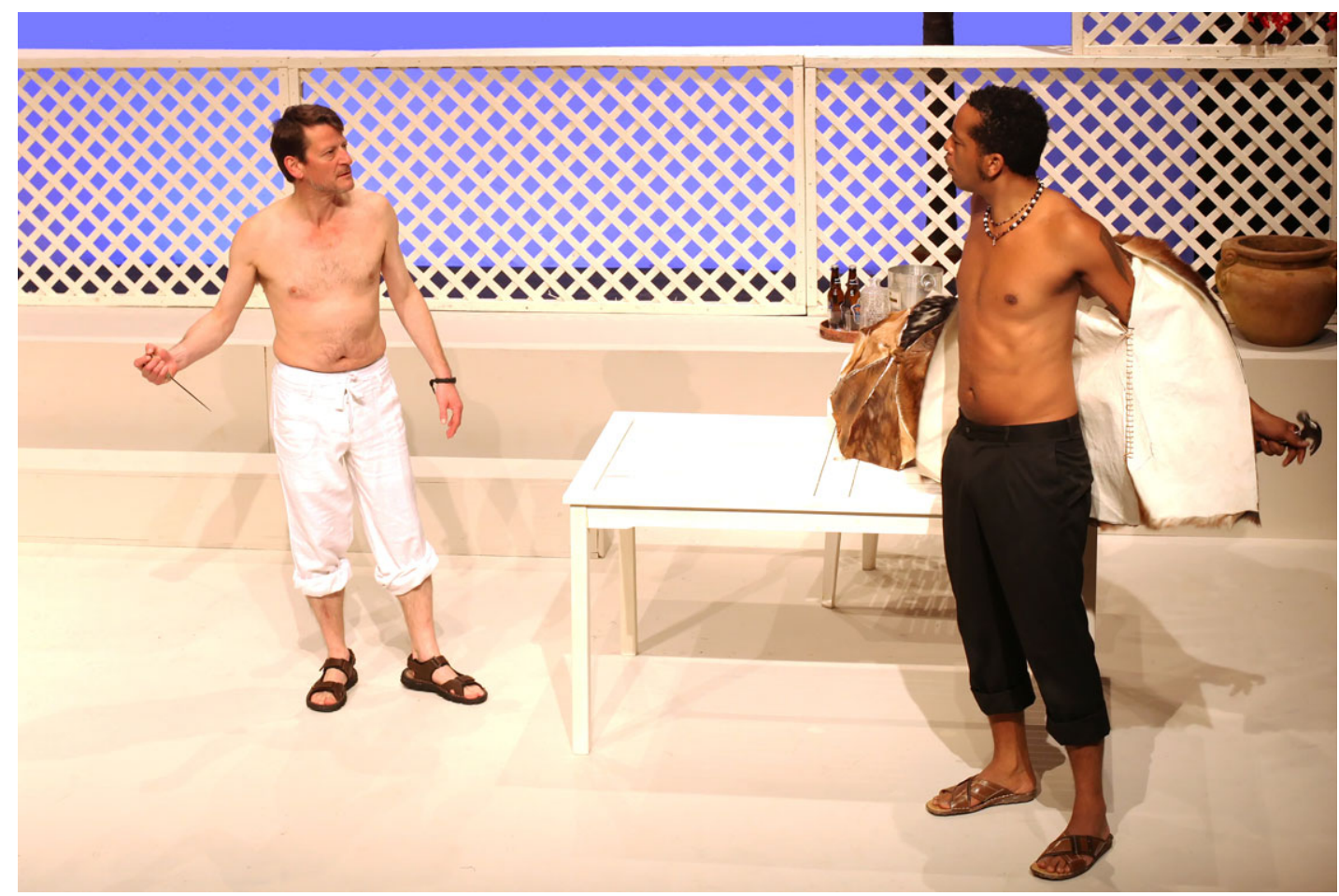

Figure 2. Pantomime, directed by Derek Walcott, University of Essex, 2012. David Tarkenter (left) and Wendell Manwarren (right). Photo: Stephanie Humphreys.

space and of bodies in space through determinations of who gets to speak, how, where, and so on. From that point of view, he mines the performative instances bound up in irony and mimicry to shine light on the embodied nature of racial ideology. The May 2012 performance staged by Walcott at the University of Essex, and featuring Wendell Manwarren of the Trinidad Theatre Workshop as Jackson and English actor David Tarkenter as Harry Trewe, vividly highlights the fact that it is not just a disembodied record that brings these two characters together and sets them against each other. History is not just 'the past', a written archive, but is a sensate knowledge of the ruptures and rebirths constitutive of racism and the ontology of Black sub-humanity. Hence Jackson's insistence on the idea of 'getting into my part': 'Well here am I getting into my part and you object. This is the story . . . This is history. This moment that we're enacting right now is the history of imperialism, nothing less than that. $^{\prime 44}$

The enduring, embodied lives of colonial mythologies cannot be ignored, as one can observe in so many public examples of racism today; nor can the coercive nature of racism, which often entails the performance of tightly defined roles. However, the use of strategies to disrupt the totalizing power of white supremacy is also a way of 'getting into one's part', since Blacks have historically been forced to use veiled, indirect performative strategies for neutralizing the power of racism. Minstrelsy has been prominent among these. Jackson's use of it, his 'playing the stage $\mathrm{n}-$ ', to use Harry Trewe's terms, functions to defamiliarize Trewe's white liberal disingenuousness and allow Jackson's otherwise demeaned voice to speak and be heard.

Although Jackson does not dare to touch Trewe directly, and only takes advantage of the absurdist performance space that has 


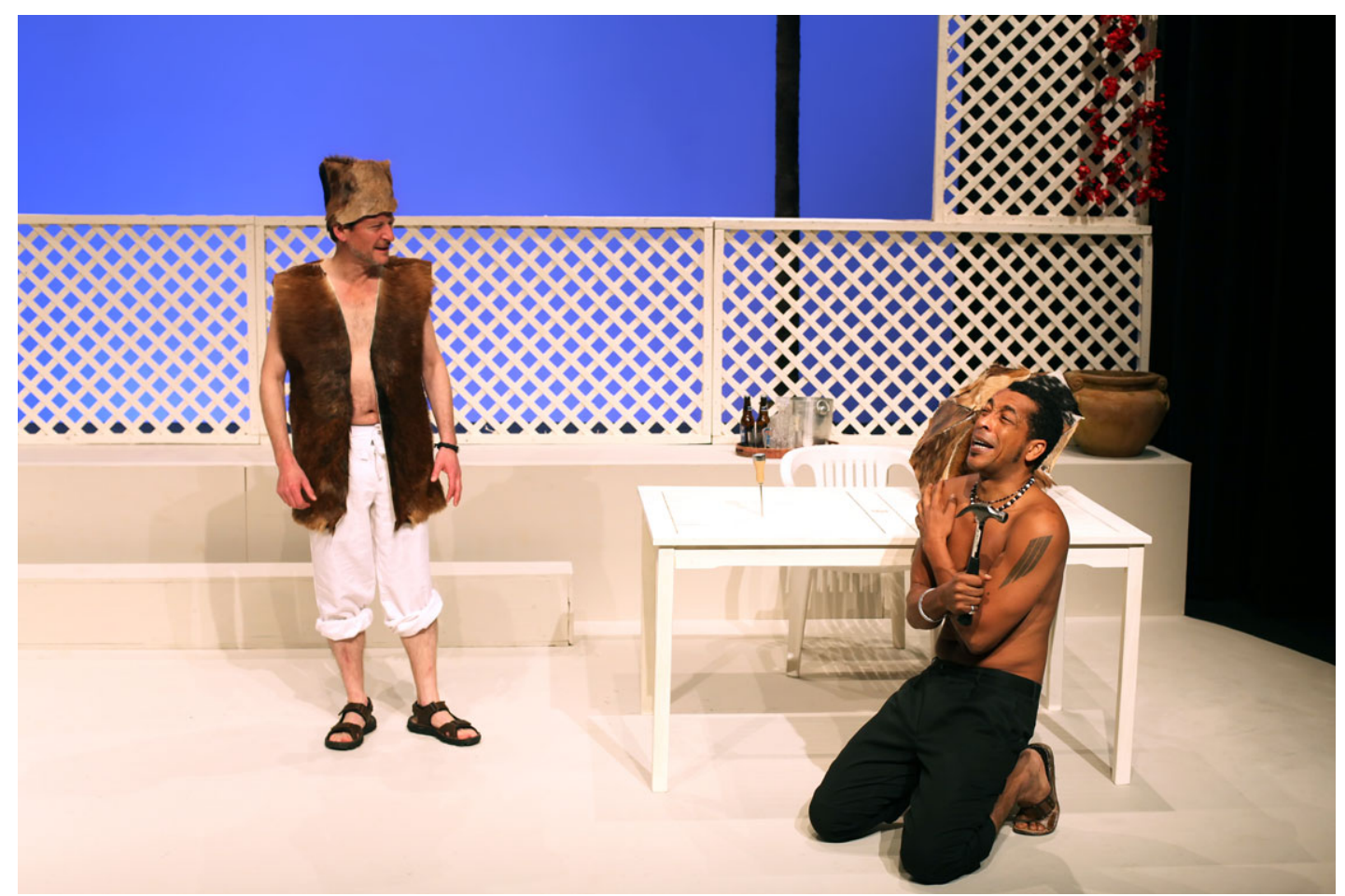

Figure 3. Pantomime, directed by Derek Walcott, University of Essex, 2012. David Tarkenter (left) and Wendell Manwarren (right). Photo: Stephanie Humphreys.

already been created, the spectator feels the aggression directed at Trewe, and the violence that is contained only by the envelope of the body. One imagines that it would be enough for Jackson to dare, at some point, to strike Mr Trewe or pounce on him. Exasperated by having only diverted and veiled possibilities of expression because of his status as an employee, by the fact of being considered less intelligent on account of his skin colour, Jackson turns Harry Trewe's stereotypes on their head. The thinly veiled aggression becomes a weapon for the agitated Jackson, who 'busies himself' (though in an ironic way) with the creation of a Crusoe island scenery in which a Black Crusoe meets a White Friday.

The memory of both lived and historical violence becomes so powerful a physical manifestation in Jackson that the body, alternating between overt and subdued convulsions, appears to be possessed. Walcott aspires to connect the spectator with the bodies on stage. Verbal dramaturgy is overtaken by a theatre of spatial language and gestures that leads the audience to perceive things sensually. In the wake of the forced abandonment of the skit, Jackson pretends to attack Harry Trewe with a hammer. At the moment when, panicstricken, Harry starts to yell, Jackson falls to his knees and begs Harry, his 'master', to 'have mercy' on Friday the 'wicked n- - ', for his aborted gesture, before finally rolling over in a fit of laughter. Other frenzied gestures on the part of Jackson help to build an atmosphere of tension and uncertainty between the two characters (Figure 3).

Jackson's resistance in the form of mimicry reflects a learned capacity for endurance that survives at the edges of discourse. The critical importance of this kind of cunning is encapsulated in one verse of a song popular among the enslaved in the United States: 'Got one mind for the boss to see; / Got another mind 
for what I know is me. ${ }^{\prime 45}$ The intention here is not to suggest an exceptionalism of the Black Caribbean body in its ability to devise cunning and slip domination. All peoples devise resistance through their bodies. However, the centrality of what Rex Nettleford calls 'cultural marronnage' in the Caribbean colonial context should be emphasized. Nettleford's notion of cultural marronnage refers to the Black Caribbean body 'as a site of acts of imagination' that disturbed 'the technologies of colonial power' ${ }^{46}$ It speaks to how Black bodies 'make meaning outside objectifying systems, through movement and voice' ${ }^{47}$

The learned capacity to elude the apparent fixity of colonial power in a way that allows survival should not be associated with a commonplace Western conception of the 'mind' that exerts its control over existence, including embodied reality. Cunning and mimicry, in this Cartesian dichotomy, would be associated with 'the mind' in its disembodied conception. Instead, Jackson relies on codes stored in his body to resist nihilistic violence. These codes are adaptations, reiterated behaviours, developed as a result of a sustained, embodied reality of violence. The significance of what Nettleford calls 'marronnage', then, is that it comes about through histories of masking, duplicity, and fugitivity that offer creative capacities for engineering space in the institution of enslavement in which 'other avenues of knowledge production were closed categorically' ${ }^{48}$ But this sensate knowledge that bodies carry within them continues to serve them in the myriad racialized spaces of modern-day society (Figure 4).

The May 2012 performance in Essex emphasizes these realities as they manifest themselves in the interaction between Jackson and the man who wants to 'bring it down to [his] level'. Upon the failure of the skit, Jackson is ordered back to work on the sun deck. His hammering on the roof he is repairing is both an expression of his repressed anger and an act of defiance. At this point, the 'normalcy' of spectatorship is pressured by the intrusive, violent noise of Jackson's hammering, by a body whose anger exceeds the shell of its

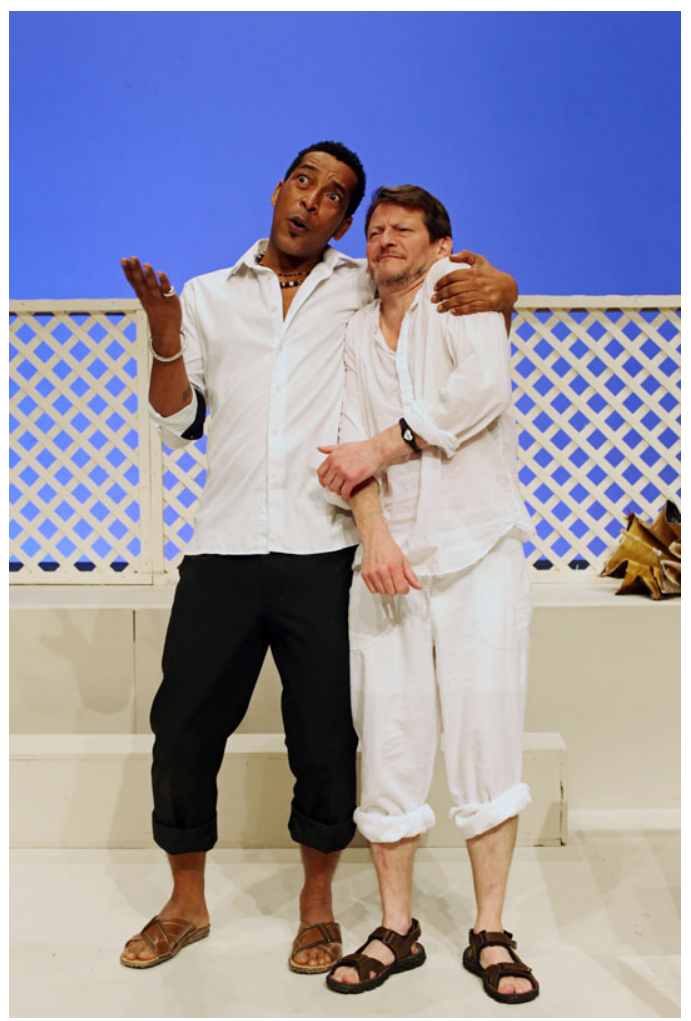

Figure 4. Pantomime, directed by Derek Walcott, University of Essex, 2012. Wendell Manwarren (left) and David Tarkenter (right). Photo: Sarah Humphreys.

physical frame. The hammering becomes a sensory disturbance, since the spectators can feel the reverberations. The convulsions and energetic gestures of the character as he prepares his mise en scène of a Black Robinson Crusoe, the bulging of his chest to address his employer, his barely controlled physical aggression towards Mr Harry Trewe, displace the need for articulated speech. The articulation of Jackson's pain and anger 'triggers a pain that exceeds the boundaries of pretence, forcing the spectator into the sentience of his or her own spectatorial sphere'. ${ }^{49}$ The spectator at this point is implicated, given the physical impact of the energy emanating from the stage. A kind of 'work' happens in them that goes beyond rationalist intellect, all the more since the two actors embody, at this stage, the affective registers of a History to which most of the spectators, if not all, are 
connected. Here, Walcott relies on the expressive power of gestures to a degree more important than the reproduction of verbal dramaturgy.

The conflict between the protagonists becomes more than a struggle of personalities. It is a microcosmos of the colonial encounter. The audience is itself part of the arena of conflict. We are in the affective force field of a historical, world-formative experience, as the play's contained poetic violence heightens the awareness of immediately exterior realities of loss, mourning, and trauma.

Pantomime thus provides an illustration of the body as a repository of ancestral stratifications of memory and being in Walcott's theatre, and as imbued with a representational excess from which 'meaning' is inseparable. In a different way to Dream on Monkey Mountain's highly visual, poetic dramaturgy, it shows that, faced with the state of permanent injury in which Black bodies are kept alive, it is the body itself that provides an anchorage point for the self to transcend the terror of colonial oppression. This paradoxical fact evidences an African/diasporic sensitivity to movement, physicality and vibrations as an essential connection to, and expression of, the life force.

\section{Conclusion}

The two performances that have been analyzed are evidently different in a number of ways. However, both plays evidence a particular understanding of the body and of embodiment. In Dream on Monkey Mountain, dance functions as a form of 'ancestralization', facilitating the return of the ancestors among the living. It is the ancestors who link the living to the idea of origins and prevent the connection to a spiritually animated universe from being lost. The ancestor is the beat of life that fuses with the dancer's own, an intelligence buried in the body. The possession rites on which Albert Laveau's Vodouand Shango-inspired choreographies are based convey a desire to reposition Black human being within an Africanist cultural matrix.
Similarly, in the gestural language of Pantomime, the past is shown to be ever present; the present re-presents the past through physical embodiments. The sense of life as a connection with ancestral worlds constitutes, for Walcott's theatre, a paradigm of durational time, physicalized by Afro-Caribbean performance energies that can ostensibly breach the rhythm of colonial time (in which the body is marked by the objectifying logics of race) and thereby impose new ways of how AfroCaribbean bodies can occupy space.

Ultimately, in these performances, Walcott is on the side of Sylvia Wynter in viewing being human in the colonial matrix as a 'praxis'. ${ }^{50}$ The body is central in this dynamic. 'Body' in the Afro-Caribbean cosmology represents a totality of being. The struggle for humanness among Walcott's AfroCaribbeans lies in the possibility, and the impulse, to repair the body and restore its relationship to reality. Memory is therefore materialized in the physicality of bodies on the stage. This, perhaps, should not be surprising, but in a theatre barely emerging in the context of newly self-governing societies (the Caribbean in the 1950s to 1980s), staging theatre with this idea in mind involved conscious and deliberate choices in aesthetic and political terms. What kind of language would be most effective for telling the traumatic history of the Caribbean, for putting into images the histories of the Black colonized body, faced with the violence of a past so tangibly felt in the physical world? As Nettleford argues, the body had to be at the centre of what it meant to make theatre in and for the Caribbean, for rhythm and embodied memory were the Caribbean's 'weapon of cultural self-defence' against (neo)colonial alienation. ${ }^{51} \mathrm{~A}$ theatre based on the actor's corporeality would allow reconnection not only to ancestral cosmogonies but also to submerged memories. For Walcott, a theatre of memory is much more than one that demonstrates the material dynamics of History; it is one that shows how such dynamics exist, and are transmitted and mediated, in both tangible and non-tangible ways (Figure 5). 


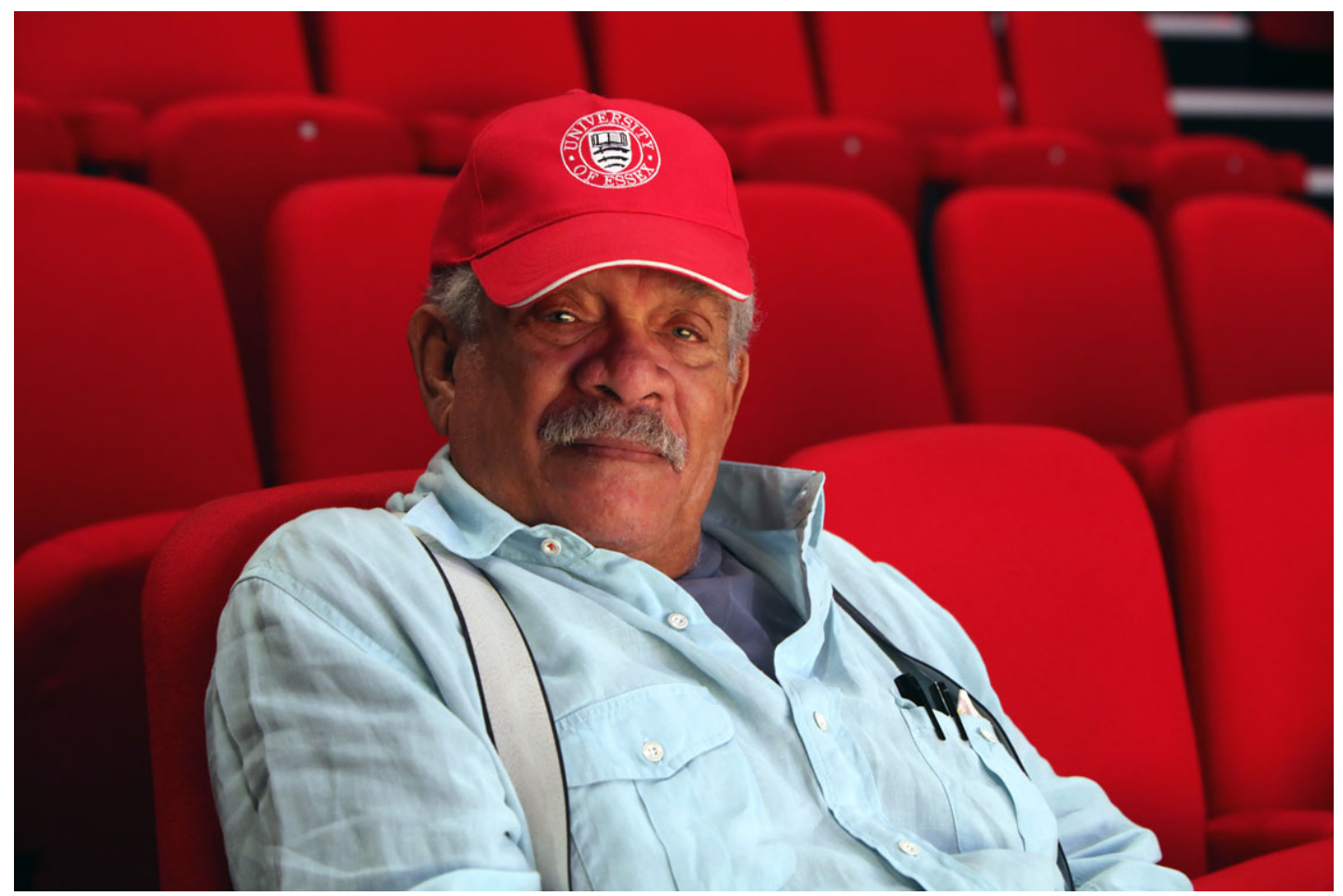

Figure 5. Derek Walcott at rehearsals of Pantomime, University of Essex, 2012. Photo: Sarah Humphreys.

\section{Notes and References}

1. Many of the foremost works of criticism on his theatre can be cited as examples of this. See, for example, Kole Omotoso, The Theatrical into Theatre: A Study of the Drama and Theatre of the English-Speaking Caribbean (London: New Beacon, 1982); Judy S. J. Stone, Theatre (London: Macmillan Caribbean, 1994); Critical Perspectives on Derek Walcott, ed. Robert D. Hamner (New York: Twayne, 1993); Edward Baugh. Derek Walcott (Cambridge: Cambridge University Press, 2006); Robert E. Fox, 'Big Night Music: Derek Walcott's Dream on Monkey Mountain and the "Splendours of the Imagination"', Critical Perspectives on Derek Walcott (Washington DC: Three Continents Press, 1993); and Teresa Bailach, 'West Indian Theatre: Derek Walcott and the Infinite Rehearsal', unpublished PhD dissertation, University of Warwick (2005). Of note, as a documentary work paying attention to the details of specific performances and tracing the developments and changings in Walcott's theatre often from the point of view of the live spectacle, is the work of Bruce King in Derek Walcott and West Indian Drama: 'Not only a Playwright but a Company': The Trinidad Theatre Workshop 1959-1993 (Oxford: Oxford University Press, 1995). King provides vital insights into the cultural and historical contexts behind the performances that will be analyzed here as part of a younger generation of critics of Walcott's theatre.

2. Derek Walcott, 'What the Twilight Says: An Overture', in Dream on Monkey Mountain and Other Plays (New York: Farrar, Straus and Giroux, 1970), p. 5.

3. Honor Ford-Smith, 'The Body and Performance in 1970 Jamaica: Toward a Decolonial Cultural Method', Small Axe, LVIII, No. 58 (2019), p. 158.
4. Ibid., p. 155 .

5. Rex Nettleford, Dance Jamaica: Cultural Definition and Artistic Discovery: The National Dance Theatre Company of Jamaica 1962-1983 (New York: Grove Press, 1985), p. 20.

6. Ford-Smith, 'The Body and Performance in 1970 s Jamaica', p. 154 .

7. Derek Walcott, 'Meanings', Critical Perspectives on Derek Walcott, ed. Hamner, p. 48.

8. Ibid., p. 47.

9. As King has remarked in Derek Walcott and West Indian Drama, Walcott's attempts at fusing West Indian body rhythms and movement with Oriental stylization are strongly evidenced in Malcochon (or Six in the Rain), a play whose Rashomon-derived inspiration is already suggested in the title.

10. Critical Perspectives on Derek Walcott, ed. Hamner, p. 48.

11. See Critical Perspectives on Derek Walcott, ed, Hamner; Bruce King, Derek Walcott: A Caribbean Life (Oxford: Oxford University Press, 200o); Paula Burnett, Derek Walcott: Politics and Poetics (Gainesville: University Press of Florida, 2001).

12. See, for example, Sandra L. Richards, 'Horned Ancestral Masks, Shakespearean Actor Boys, and Scotch-Inspired Set Girls: Social Relations in Nineteenth-Century Jamaican Jonkonnu', in Isidore Okpewho, Carol Boyce Davies, and Ali A. Mazrui, ed., The African Diaspora: African Origins and New World Identities (Bloomington: Indiana University Press, 1999), p. $254-74$

13. Bertolt Brecht, Brecht on Theatre, translation and notes by John Willett (Methuen: London, 1964), p. 203. 
14. Walter Benjamin, 'Theses on the Philosophy of History', in Illuminations: Essays and Reflections, ed. Hannah Arendt (New York: Schocken Books, 1969), p. 253-64.

15. Walter Benjamin, Understanding Brecht (London: Verso, 1998), p. 8.

16. Christina Sharpe, In the Wake: On Blackness and Being (Durham: Duke University Press, 2016).

17. Innes María Martiatu Terry, 'Mythological and Ritual Theatre in Cuba', Performance Research: A Journal of the Performing Arts, III (2014), p. 53.

18. Anthony Hozier, 'Ritual', in The Continuum Companion to Twentieth-Century Theatre, ed. Colin Chambers (London: Continuum, 2002), p. 650.

19. Richard Walsh, 'Radical Theatre in the Sixties and Seventies', BAAS Pamphlet in American Studies, XXIV (1993), <https:/ / www.baas.ac.uk/richard-walsh-radicaltheatre-in-the-sixties-and-seventies $/>$.

20. Sylvia Wynter, 'Jonkonnu in Jamaica: Towards the Interpretation of Folk Dance as a Cultural Process', in Sylvia Wynter, We Must Learn to Sit Together and Talk About a Little Culture: Decolonizing Essays 1967-1984 (Leeds: Peepal Tree Press, 2018), p. 192-243; M. NourbeSe Philip, 'African Roots and Continuities: Race, Space and the Poetics of Moving', in A Genealogy of Resistance (Toronto: The Mercury Press, 1997), p. 201-33.

21. Walcott, 'What the Twilight Says', p. 5.

22. Ibid., p. 7 .

23. Jerzy Grotowski, Towards a Poor Theatre (London: Methuen, 1991), p. 36.

24. James Slowiak and Jairo Cuesta, Jerzy Grotowski (London: Routledge, 2007), p. 32.

25. Derek Walcott, 'What the Twilight Says', p. 6.

26. Derek Walcott, 'Meanings', p. 47.

27. Ibid., p. 48.

28. Derek Walcott, 'What the Twilight Says', p. 5 .

29. See Janice Boddy, 'Spirit Possession Revisited: Beyond Instrumentality', Annual Review of Anthropology, XXIII (1994), p. 407-34; Paul Stoller, Embodying Colonial Memories: Spirit Possession, Power, and the Hauka in West Africa (New York: Routledge, 1995).

30. Maya Deren, The Divine Horsemen: The Living Gods of Haiti (New York: McPherson \& Co., 2004), p. 24.

31. See Rhonda Cobham, "“A Wha Kind a Pen Dis?": The Function of Ritual Frameworks in Sistren's Bellywoman Bangarang', Theatre Research International, XV (1990), p. 233-49.

32. Walcott, Dream on Monkey Mountain, p. 222.
33. Ibid., p. 227.

34. Ibid., p. 229.

35. Sabine Sörgel, Dancing Postcolonialism: The National Dance Theatre Company of Jamaica (Bielefeld: Transcript Verlag, 2007), p. 64; King, Derek Walcott and West Indian Drama, p. 25.

36. Walcott, Dream on Monkey Mountain, p. 208; see also King, Derek Walcott and West Indian Drama, p. 89.

37. Sörgel, Dancing Postcolonialism, p. 6o; King, Derek Walcott and West Indian Drama, p. 26.

38. Wynter, 'Jonkonnu in Jamaica', p. 202-3.

39. Jean-Paul Sartre, 'Prologue to Frantz Fanon's The Wretched of the Earth', in Walcott, Dream on Monkey Mountain, p. 211.

40. See Derek Walcott, Derek Walcott: The Journeyman Years. Volume 2: Performing Arts: Occasional Prose 19571974, ed. Christopher Balme and Gordon Collier (Amsterdam: Rodopi, 2013), p. 238-45; Walcott, 'What the Twilight Says', p. 25-7.

41. Derek Walcott: The Journeyman Years, p. 239

42. Ibid., p. 240.

43. Christopher Balme, Decolonizing the Stage: Theatrical Syncretism and Postcolonial Drama (Oxford: Oxford University Press, 1999), p. 99.

44. Derek Walcott, Pantomime, in Remembrance and Pantomime (New York: Farrar, Straus and Giroux, 1980), p. 125 (my emphasis).

45. Julius Lester, To Be a Slave (New York: Laurel-Leaf Library, 1968), p. 100, quoted in Clinton Hutton, 'The Creative Ethos of the African Diaspora: Performance Aesthetics and the Fight for Freedom and Identity, Caribbean Quarterly, LIII (2007), p. 128.

46. Anthony Bogues, 'Rex Nettleford: The Canepiece, Labour, Education and the Caribbean Intellectual', Caribbean Quarterly, LVII (2011), p. 27.

47. Ford-Smith, "The Body and Performance in 1970 s Jamaica', p. 157.

48. Ibid., p. 155 .

49. Stanton Garner, Bodied Spaces: Phenomenology and Performance in Contemporary Drama (Ithaca, New York; London: Cornell University Press, 1994), p. 42-3.

50. Sylvia Wynter, 'Human Being as Noun? Or Being Human as Praxis? Towards the Autopoetic Turn/Overturn: A Manifesto', <http://bcrw.barnard.edu/wpcontent/uploads/2015/10/Wynter_TheAutopoeticTurn. pdf $>$, accessed 26 June 2020.

51. Rex Nettleford, Dance Jamaica, p. 20. 